\title{
Efektivitas Pemberian Bantuan Hukum Struktural dalam Proses Penyelesaian Perkara Pidana Secara Litigasi dan Non-Litigasi
}

\section{The Effectiveness of Providing Structural Legal Aid in the Litigation and Non-Litigation Process of Criminal Case Resolution}

\author{
Fajargus Laia, Susilawati \& Maria Rosalina
}

Program Stud Ilmu Hikum, Fakultas Hukum, Universitas Islam Sumatera Utara, Indonesia

Diterima: 23 September 2020; Direview: 26 September 2020; Disetujui: 17 November 2020

*Email: fajarguslaia@gmail.com

\begin{abstract}
Abstrak
Tujuan penulisan ini adalah untuk mengetahui pengaturan hukum terhadap pemberian bantuan hukum struktural, apa saja bentuk penyelesaian secara litigasi dan non litigasi, dan bagaimana hambatan yang dihadapi. Penelitian bersifat deskriptif, dengan menggambarkan keadaan subjek dan objek dapat berupa orang atau lembaga berdasarkan fakta yang ada dan menggunakan pendekatan yuridis normative dan empiris yaitu menganalisis peraturan perundang-undangan dan melakukan wawancara dengan responden. Data diperoleh melalui penelitian lapangan (field research). Berdasarkan hasil penelitian, pengaturan dalam memberikan bantuan hukum struktural oleh lembaga bantuan hukum medan yaitu Undang-undang No.16 Tahun 2011 tentang bantuan hukum dan Peraturan Pemerintah No. 42 Tahun 2013 sebagai peraturan pelaksananya, dan adapun bantuan internal yaitu standar operasional prosedur lembaga bantuan hukum itu sendiri dan undang-undang lain yang menunjang. Lembaga bantuan hukum medan menyelesaikan perkara pidana secara litigasi dan non litigasi. Penyelesaian secara litigasi adalah penanganan perkara melalui jalur pengadilan, yaitu bertindak sebagai pendamping, baik di kepolisian, dikejaksaan, dan dipersidangan. Sedangkan penyelesaian secara non litigasi adalah penanganan perkara diluar jalur pengadilan, yaitu dengan melakukan penyuluhan hukum, konsultasi hukum, mediasi, dan negoisasi, dapat dilakukan oleh advokat, paralegal, dosen, dan mahasiswa fakultas hukum yang telah memenuhi persyaratan yang telah ditetapkan.
\end{abstract}

Kata Kunci: Bantuan Hukum; Perkara Pidana; Struktural

\begin{abstract}
The purpose of this paper is to determine the legal arrangements for providing structural legal aid, what are the forms of litigation and non-litigation resolution, and how the obstacles are faced. The research is descriptive in nature, by describing the state of the subject and object, which can be people or institutions based on existing facts and uses a normative and empirical juridical approach, namely analyzing laws and regulations and conducting interviews with respondents. Data obtained through field research (field research). Based on the results of the research, the arrangements for providing structural legal aid by the Medan legal aid agency are Law No.16 of 2011 concerning legal aid and Government Regulation No. 42 of 2013 as the implementing regulation, and as for internal assistance, namely the standard operating procedures of the legal aid agency itself and other supporting laws. Field legal aid agencies resolve criminal cases in litigation and non-litigation terms. Litigation resolution is the handling of cases through court channels, namely acting as a companion, both in the police, prosecutors, and in court. Meanwhile, nonlitigation settlement is the handling of cases outside the court route, namely by conducting legal counseling, legal consultation, mediation, and negotiations, which can be carried out by lawyers, paralegals, lecturers, and law faculty students who have met the requirements that have been set.

Keywords: Legal Aid; Criminal Case; Structural

How to Cite: Laia, F., Susilawati, S., \& Rosalina, M. (2020). Efektivitas Pemberian Bantuan Hukum Struktural dalam Proses Penyelesaian Perkara Pidana Secara Litigasi dan Non-Litigasi. Journal of Education, Humaniora and Social Sciences (JEHSS). 3 (2): 750-760.
\end{abstract}




\section{PENDAHULUAN}

Persoalan bantuan hukum di Indonesia adalah berhubungan erat dengan sifat Negara kita sebagai suatu negara hukum dan konsekuensi dari pada di akuinya prinsip Negara Indonesia adalah negara hokum (Abdurrahman, 1983). Negara berdasarkan Undang-undang Nomor 16 Tahun 2011 tentang Bantuan Hukum (selanjutnya di sebut UU Bantuan Hukum) menjamin hak konstitusional bagi setiap orang atau warga negaranya untuk mendapatkan pengakuan, jaminan, perlindungan dan kepastian hukum yang adil serta perlakuan yang sama di hadapan hukum sebagai sarana perlindungan hak asasi manusia.

Dalam prakteknya, penegakan persamaan di muka hukum sulit tercapai terutamajika yang tersandung kasus hukum adalah golongan masyarakat yang tidak mampu atau miskin yang pada umumnya tidak mengetahui hukum (buta hukum). Mereka yang tidak mampu bahkan buta hukum ini terkadang tidak mengetahui hak-hak mereka yang pada dasarnya sudah diatur dalam undangundang karena sebagian besar dari mereka terpaku dengan anggapan bahwa ketika mereka ingin membela hak-hak mereka, mereka harus mengeluarkan biaya besar yang mungkin untuk makan saja mereka masih kesulitan. Hal ini dilatar belakangi oleh sangat minimnya sosialisasi terkait hakhak mereka ketika menghadapi kasus hukum.Terlebih lagi, maraknya stigma mahalnya biaya untuk membayar jasa advokat atau pengacara.

Pengadilan sebagai pelaksana hukuma dalah suatu lembaga yang akan memberikan keadilan bagi mereka yang mencari keadilan, tidak peduli siapapun dan bagaimanapun latarbelakangnya. Namun pada kenyataannya hukum sejak semula selalu mengandung potensi untuk cenderung memberikankeuntungan kepada mereka dari golonganyang lebih mampu secara financial (Rahardjo, 2003). Dalam sistem peradilan di Indonesia, tidak sedikit dari putusan-putusan pengadilan yang justru jauh dari harapan masyarakat.Ia hanya mengacu pada aturanaturanformal belaka. Pengadilan yang seharusnyamenjadi tempat untuk menemukan keadilan berubah menjadi medan perang untuk mencari kemenangan (to win the case) (Sudirman, 2007). Padaprinsipnya mekanisme penyelesaian perkaramelalui pengadilan bersifat win lose solution.

Kemiskinan merupakan permasalahan yang sangat kompleks, yang tidak hanya terbatas pada permasalahan ekonomi saja tetapi juga berkaitan dengan permasalahan di bidang lain. Kebijakan dari pemerintah sangat dibutuhkan di dalam membantu memecahkan persoalan terkait kemiskinan pada bidang-bidang lainnya, contohnya dalam bidang hukum. Memang benar, kemiskinan secara global diartikan sebagai kemiskinan dalam batas materi, yang dapat diukur dengan nominal sejumlah uang dalam bentuk rupiah atau dapat dikaitkan pada nominal upah minimum regional di setiap-setiap daerah di Indonesia (Sihombing, 2019). Akan tetapi, ketika kemiskinan bersinggungan dengan bidang hukum, hukum hanya milik orang-orang yang mempunyai uang dan pemberian bantuan hukum juga hanya dapat di nikmati oleh orang-orang yang mempunyai uang, sementara orang-orang miskin atau marginal tidak memperoleh kesempatan tersebut karna ketidak mampuan dalam segi ekonomi. Oleh karna itu untuk dapat membantu menyelesaikan persoalan hukum yang ada, maka orang yang berhadapan dengan persoalan hukum tersebut diberikan hak untuk mendapatkan bantuan hukum agar dapat membela dirinya (Rosalina, 2018).

Semua orang di pandang sama dihadapan hukum (equality before the law) tertuang dalam Pasal 27 Ayat (1) UUD 1945, yang menyebutkan bahwa segala warga negara bersamaan kedudukannya di dalam hukum dan pemerintahan dan wajib menjunjung hukum dan pemerintahan itu dengan tidak ada kecualinya.

Sistem equality before the law yang menuntut kesamaan kedudukan warga negara di muka hukum ini terkadang tidak di mengerti oleh warga negara sendiri khususnya bagi rakyat kecil yang menjalani kasus-kasus hukum terutama kasus pidana. Sebagian besar dari mereka justru lebih ikhlas atau rela hak-hak mereka dibuang percuma karena mereka berpendapat bahwa memperjuangkan hak-hak mereka dalam kasus hukum justru akan merugikan mereka dari segi materil. Hal ini disebabkan karena mereka menyaksikan maraknya berita-berita yang beredar di berbagai media massa yang menunjukkan bahwa menjalani kasus hukum harus mengeluarkan biaya yang tidak sedikit. Karna ketidaktauan, takut, dan biaya mahal sehingga mereka tidak di 
dampingi oleh advokad atau penasehat hukum, akibatnya hak mereka di rugikan dengan hukuman pidana yang berat.

Negara memahami permasalahan ini dengan dikeluarkannya UU Bantuan Hukum sebagai tindakan nyata dalam melindungi persamaan kedudukan warga negaranya di muka hukum. Yayasan lembaga bantuan hukum salah satunya Lembaga Bantuan Hukum Medan (selanjutnya di sebut LBH Medan) adalah lembaga yang menjalankan tugas dan profesinya sebagai pemberi bantuan hukum yang bekerja secara profesional dengan tetap berpedoman kepada aturan hukum yang berlaku, dan selalu siap dan efektif untuk membantu masyarakat khususnya kurang mampu dalam mendampingi, membela dan memberikan bantuan hukum struktural dalam proses penyelesaian perkara baik secara litigasi dan non-litigasi.

Adapun penyelesaian perkara pidana yaitu dengan cara penyelesaian secara litigasi dan nonlitigasi. Penyelesaian secara litigasi merupakan proses penyelesaian sengketa di pengadilan. Dan penyelesaian secara non-litigasi yaitu penyelesaian sengketa di luar proses peradilan (www.komisiinformasi.bantenprov.com).

Dalam pemberian pelayanan bantuan hukum kepada masyarakat miskin oleh LBH Medan harus di jalankan sesuai asas dan tujuan UU Bantuan Hukum, yaitu asas keadilan, persamaan kedudukan dimata hukum, keterbukaan, efesiensi, efektivitas dan akuntabilitas, sehingga terciptanya penyelenggaraan bantuan hukum yang efektif.

Perkara yang di tangani LBH hanya yang berkaitan kepentingan publik, misalnya penggusuran, penodaan agama, dll. Sedangkan untuk kasus-kasus lainnya seperti kasus perdata yang bersifat komersial, bisnis atau perceraian hanya akan di berikan konsultasi.

Pada tahun-tahun sebelumnya banyak kasus pidana dan perdata yang di tangani oleh LBH Medan,di tahun 2014 kasus pidana yang di adukan masyarakat kepada LBH Medan sebanyak 135 kasus dan kemudian di tahun 2015 menurun menjadi 40 kasus. Kemudian dalam kasus perdata tercatat di tahun 2014 sebanyak 110 kasus dan di tahun 2015 mengalami penurunan sebanyak 36 kasus sehingga menjadi 63 kasus saja yang di tangani oleh LBH Medan. Namun, perjuangan LBH Medan di pengadilan dalam menangani kasus-kasus itu silih berganti mengalami menang dan kalah di pengadilan.Tetapi soal itu adalah biasa dan tidak sampai mengurangi apresiasi kepercayaan masyarakat terhadap LBH Medan.

Berdasarkan uraian diatas peneliti tertarik untuk melakukan penelitian dalam rangka menyelesaikan studi pada Program Studi S1 Ilmu Hukum Fakultas Hukum Universitas Islam Sumatera Utara, dengan judul: Efektivitas Pemberian Bantuan Hukum Struktural Dalam Proses Penyelesaian Perkara Pidana Secara Litigasi Dan Non-litigasi (studi penelitian pada Lembaga Bantuan Hukum Medan).

\section{METODE PENELITIAN}

Objek dalam penelitian ini adalah efektivitas pemberian bantuan hukum struktural dalam proses penyelesaian perkara pidana secara litigasi dan non-litigasi. Adapun lokasi penelitian ini akan dilaksanakan di Kantor Lembaga Bantuan Hukum Medan, yang beralamat di Jalan Hindu No. 12 Medan, Sumatera Utara, Kota Medan.

Penelitian ini bersifat deskriptif dengan menggambarkan keadaan subjek dan objek dalam penelitian yang dapat berupa orang, lembaga, masyarakat dan yang lainnya berdasarkan faktafakta yang tampak atau apa adanya, Penelitian yang bertitik tolak dari permasalahan yang melihat kenyataan yang terjadi di lapangan dengan melakukan wawancara dengan narasumber di Kantor Lembaga Bantuan Hukum Medan.

Metode pendekatan yang dipergunakan dalam penelitian ini adalah dengan pendekatan yuridis normatif dan empiris.Pendekatan yuridis normatif dipergunakan untuk menganalisis peraturan perundang-undangan.Pendekatan yuridis empiris yaitu dengan memperoleh data-data yang relevan melalui wawancara dengan responden yang ada di Kantor Lembaga Bantuan Hukum Medan.

Sumber data dalam penelitian ini adalah: 1) Bahan hukum primer yaitu bahan-bahan hukum yang mengikat antara lainUndang-Undang Republik Indonesia Nomor 18 Tahun 2003 tentang 752 http://mahesainstitute.web.id/ojs2/index.php/jehss mahesainstitut@gmail.com 
Advokat, Undang-Undang Republik Indonesia Nomor 16 Tahun 2011 tentang Bantuan Hukum; 2) Bahan hukum sekunder yaitu bahan yang memberikan penjelasan tentang bahan hukum primer antara lain tulisan atau pendapat pakar hukum mengenaiefektivitas pemberian bantuan hukum structural dalam proses penyelesaian perkara pidana secara litigasi dan non-litigasi; 3) Bahan hukum tersier yaitu berupa kamus besar bahasa Indonesia dan kamus istilah hukum.

Dalam pengumpulan data menggunakan teknik pengumpulan data yaitu: 1) Penelitian kepustakaan (library research) yaitu dengan mempelajari buku-buku yang berkaitan dengan pembahasan, perundang-undangan, pendapat para sarjana dan bahan-bahan perkuliahan yang dimaksudkan untuk mengumpulkan data sekunder; 2) Penelitian lapangan (field research) yaitu pengumpulan data di lapangan yang relevan dengan permasalahan dalam Skripsi ini dan melakukan wawancara di Kantor Lembaga Bantuan Hukum Medan.

Data yang terkumpul tersebut dianalisis dengan seksama dengan menggunakan analisis kualitatif atau dijabarkan dengan kalimat. Analisis kualitatif adalah analisis yang didasarkan pada paradigma hubungan dinamis antara teori, konsep-konsep dan data yang merupakan umpan balik atau modifikasi yang tetap dari teori dan konsep yang di dasarkan pada data yang dikumpulkan.

\section{HASIL DAN PEMBAHASAN}

\section{Pengaturan Hukum Terhadap Pemberian Bantuan Hukum Struktural Dalam Proses Penyelesaian Perkara Pidana Secara Litigasi Dan Non-Litigasi}

Bantuan hukum dikenal dengan istilah legal aid.Istilah legal aid biasanya dipergunakan untuk menunjukan pengertian bantuan hukum dalam arti sempit berupa pemberian jasa di bidang hukum kepada seorang yang terlibat dalam suatu perkara secara cuma-cuma atau gratis, khususnya bagi mereka yang kurang mampu. Pegertian bantuan hukum mempunyai ciri dalam istilah yang berbeda yaitu: 1) Legal aid adalah bantuan hukum sistem nasional yang di atur secara lokal dimana bantuan hukum ditunjukan bagi mereka yang kurang mampu keuangannya dan tidak mampu membayar penasehat hukum pribadi; 2) Legal assistance adalah lebih memaparkan profesi dari penasehat hukum sebagai ahli hukum. Legal assistance dapat menyediakan jasa bantuan hukum untuk siapa saja tanpa terkecuali. Legal assistance dipergunakan untuk menunjukan pengertian bantuan hukum oleh para advokat yang mempergunakan honorium (Sunggono dan Harianto, 1994).

Pada umumnya kebanyakan orang lebih cenderung memberi pengertian yang lebih luas kepada konsep dan makna legal service di bandingkan dengan konsep dan tujuan legal aid atau legal assistance. Karena pada konsep dan ide legal service terkandung makna dan tujuan: 1) Memberi bantuan kepada anggota masyarakat yang operasionalnya bertujuan menghapuskan kenyataan-kenyataan diskriminatif dalam penegakan dan pemberian jasa bantuan antara rakyat miskin yang berpenghasilan kecil dengan masyarakat kaya yang menguasai sumber dana dan posisi kekuasaan; 2) Dengan pelayanan hukum yang diberikan kepada anggota masyarakat yang memerlukan, dapat di wujudkan kebenaran hukum itu sendiri oleh aparat penegak hukum dengan jalan menghormati setiap hak yang dibenarkan hukum bagi setiap anggota masyarakat tanpa membedakan yang kaya dan miskin; Di samping untuk menegakkan hukum dan penghormatan kepada hak yang di berikan hukum kepada setiap orang, legal servicedidalam operasionalnya, lebih cenderung untuk menyelesaikan setiap persengketaan dengan jalan menempuh cara perdamaian (Harahap, 1999).

Adapun bantuan hukum dalam pengertian yang paling luas dapat di artikan sebagai upaya untuk membantu golongan yang tidak mampu dalam bidang hukum. Menurut Adnan Buyung, upaya ini mempunyai tiga aspek yang saling berkaitan, yaitu aspek perumusan aturan-aturan hukum, aspek pengawsan terhadap mekanisme untuk menjaga agar aturan itu di taati, dan aspek pendidikan masyarakat agar aturan-aturan itu dihayati (Buyung, 1988).

Adapun peraturan yang mengatur tentang bantuan hukum sebagai jaminan keadilan dalam melindungi hak-hak masyarakat miskin atau tidak mampu saat ini adalah: Undang-undang Nomor 16 Tahun 2011 Tentang Bantuan Hukum (selanjutnya disebut UU Bantuan Hukum) 
Secara garis besar UU Bantuan Hukum mengatur tata cara pemberian bantuan hukum secara cuma-cuma kepada penerima bantuan hukum yang didalamnya adalah orang atau kelompok orang miskin yang menghadapi masalah hukum. Pemberi bantuan hukum yang telah memenuhi syarat UU Bantuan Hukum ini berhak merekrut advokat, paralegal, dosen, dan mahasiswa fakultas hukum dalam melakukan pelayanan bantuan hukum yang meliputi litigasi dan non litigasi.

Pemerintah Indonesia juga telah menegaskan jaminannya terhadap hak konstitusional setiap orang untuk mendapatkan pengakuan, perlindungan, kepastian hukum yang adil dan perlakuan yang sama di hadapan hukum, serta akses keadilan sebagai bagian dari sarana perlindungan hak asasi manusia.

Berdasarkan hasil wawancara dengan respondenmenyebutkan bahwa selain UU Bantuan Hukum lembaga bantuan hukum memiliki pedoman dan acuan atau dasar hukum dalam memberikan bantuan hukum yaitu PP No 42 Tahun 2013 sebagai peraturan pelaksananya, dan adapun bantuan internal yaitu Standar Operasional Prosedur (SOP) lembaga bantuan hukum itu sendiri sebagai acuan dalam memberikan bantuan hukum dan peraturan-peraturan lain yang menunjang (Hasil Wawancara dengan Irvan saputra, Advokat Lembaga Bantuan Hukum Medan, Tanggal 16 Juli 2019, Pukul 15.20 Wib).

Peraturan-peraturan lain yang menunjang disini salah satunya adalah Kitab Undang-undang Hukum Acara Pidana (selanjutnya di sebut KUHAP). Dalam KUHAP sendiri, diisyaratkan bahwa bantuan hukum merupakan asas hukum acara pidana yang penting, karena setiap orang yang tersangkut perkara pidana diberi kesempatan memperoleh bantuan hukum yang semata-mata di berikan untuk melaksanakan kepentingan pembelaan atas dirinya. Bantuan hukum dalam proses peradilan pidana adalah suatu prinsip negara hukum yang dalam tahap pemeriksaan pendahuluan di wujudkan dengan menentukan keperluan penyiapan pembelaan, tersangka terutama sejak saat dilakukan penangkapan dan atau penahanan, berhak untuk menunjuk dan menghubungi serta minta bantuan penasehat hukum. Hal ini mengandung arti bahwa dalam negara hukum itu terletak cirri-ciri yang mendasar yaitu: 1) Pengakuan dan perlindungan atas hak asasi manusia yang mengandung persamaan dalam bidang politik, hukum, sosial, kultur, dan pendidikan; 2) Peradilan yang bebas, dan tidak memihak, serta tidak di pengaruhi oleh kekuasaan apapun; 3) Legalitas dalam arti hukum dalam semua bentuknya (Kusnadi dan Saragih, 1983).

Dari penjelasan di atas, maka peran pemerintah dalam setiap rencana atau program bantuan hukum bersifat menentukan konsep apakah yang akan di pakai dalam penyelenggaraan peradilan pidana guna melindungi HAM tersangka, terdakwa serta terpidana. Bantuan hukum, biasanya merupakan program hukum untuk membantu pencari keadilan bagi rakyat kecil yang tidak mampu dan relatif buta hukum khususnya, dapat membantu pencapaian pemerataan keadilan karena kian dipermudah usaha-usaha semisal terbinanya sistem peradilan pidana yang terpadu (Sugono, 2017).

Bantuan hukum kepada rakyat kecil (miskin), diberikan kepada tersangka sejak ia ditangkap atau ditahan pada semua tingkat pemeriksaan, baik dalam tingkat penyidikan, maupun dalam tingkat pemeriksaan di pengadilan. Dalam pemeriksaan tingkat penyidikan, tersangka di dampingi oleh penasehat hukum, akan tetapi penasehat hukum tersebut hanya bersifat pasif (diam, mendengarkan, tidak boleh berbicara), sebagaimana yang di sebutkan dalam Pasal 74, Pasal 115 Ayat (1), dan Pasal 156 KUHAP.

Peran serta advokat sangat fundamental untuk terselenggaranya bantuan hukum itu, terutama dalam tugas-tugas litigasi ketika mengadvokasi penerima bantuan hukum.Dalam memberikan bantuan hukum tersebut erat hubungannya dengan sifat negara kita yaitu negara hukum sehingga dalam pelaksanaannya diserahkan kepada masyarakat melalui lembaga bantuan hukumatau organisasi kemasyarakatan yang telah memenuhi persyaratan-persyaratan dalam undang-undang atau peraturan-peraturan dibawahnya.Sementara dalam undang-undang advokat yang dititik beratkan merupakan kewajiban seorang advokat sebagai officium nobille. Meskipun demikian undang-undang bantuan hukum ini menjelaskan tentang posisi advokat menjadi bagian dari pemberi bantuan hukum yang bernaung dalam wadah lembaga bantuan hukum atau organisasi kemasyarakatan.

754 http://mahesainstitute.web.id/ojs2/index.php/jehss

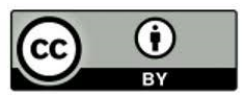


Dalam memberikan bantuan hukum maka diharapkan tidak ada kesalahan penafsiran menyangkut ruang lingkup pemberi bantuan hukum antara UU Advokat dengan UU Bantuan Hukum dalam memberikan bantuan hukum secara cuma-cuma.Prinsipnya adalah tanpa bernaung dalam lembaga bantuan hukum atau organisasi kemasyarakatan, seorang advokat tetap memiliki peran untuk memberikan bantuan hukum dengan cuma-cuma bagi orang yang tidak mampu (miskin). Dalam konteks undang-undang, bantuan hukum ini dapat dijelaskan tentang cara menjalankan proses konsultasi, pendidikan hukum, investigasi dan dokumentasi dapat dilakukan oleh pembela masyarakat lain, namun untuk menghadap kepersidangan tetap harus di lakukan seorang advokat. cara mengatasinya biasanya dilakukan dengan merekrut pengacara sukarela, yaitu advokat yang menjadi relawan (paruh waktu) di organisasi bantuan hukum dengan menyiapkan segala sesuatu untuk kepentingan persidangan.

\section{Bentuk Penyelesaian Perkara Pidana Secara Litigasi Dan Non-Litigasi Berdasarkan Undang-Undang Nomor 16 Tahun 2011}

Bentuk penyelesaian perkara pidana yang dilakukan pemberi bantuan hukum kepada penerima bantuan hukum yaitu penyelesaian secara litigasi dan non litigasi.

Bantuan hukum dalam tahapan litigasi, pemberian bantuan hukum secara litigasi dilakukan oleh advokat yang berstatus sebagai pengurus pemberi bantuan hukum dan/atau advokat yang terdaftar pada pemberi bantuan hukum. Jika advokat tidak memadai pemberian bantuan hukum dapat merekrut advokat, paralegal, dosen, dan/atau mahasiswa fakultas hukum dengan memberikan surt perintah tugas pembantuan bantuan hukum dari direktur atau ketua pemberi bantuan hukum terhadap hasil rekrutmen.

Pemberian bantuan hukum secara litigasi sebagaimana dimaksud dalam Pasal 13 PP No 42 Tahun 2013 dilakukan dengan cara pendampingan dan atau menjalankan kuasa yang dimulai dari tingkat penyidikan dan penuntutan, atau pemeriksaan di persidangan.

Sebelum penyidik melakukan pemeriksaan terhadap seseorang yang di sangka melakukan suatu tindak pidana, maka penyidik wajib memberitahukan kepadanya tentang haknya untuk mendapatkan bantuan hukum atau dalam perkara tersebut, tersangka wajib didampingi oleh penasehat hukum.

Dalam memberikan bantuan hukum LBH melakukan pendampingan hingga sampai tahap di pengadilan negeri saja dan tidak tertutup kemungkinan jika banding dan kasasi di periksa ulang di Pengadilan Negeri maka harus di berikan pendampingan (Hasil Wawancara dengan Irvan Saputra, Advokat Lembaga Bantuan Hukum Medan, Tanggal 16 Juli 2019, Pukul 15.20 Wib.).

Perkara yang berhak mendapatkan bantuan hukum adalah perkara pidana yang di ancam pidana lima tahun atau lebih, perkara pidana yang diancam pidana mati, atau perkara pidana yang di ancam hukuman penjara lima tahun namun menarik perhatian masyarakat luas.

Perkara yang di sebutkan di atas, wajib mendapatkan bantuan hukum sesuai dengan asas contante justitieserta dengan pertimbangan bahwa tersangka atau terdakwa dalam perkara semacam ini dapat di kenakan penahanan.

Dalam tingkat penyidikan, bantuan hukum di berikan kepada tersangka sebelum dilakukan pemeriksaan akan haknya untuk di damping oleh penasehat hukum selama di lakukan pemeriksaan, dan berhak memperoleh atau di damping oleh penasehat hukum yang wajib disedikn penyidik walaupun tersangka tidak menghendaki. Hak bantuan hukum bagi tersangka tersebut di atas berlaku juga bagi terdakwa pada saat atau tahap penuntutan dan pemeriksaan di pengadilan, bahkan hak tersebut di miliki oleh terdakwa sampai dengan terjadinya proses upaya hukum setelah adanya putusan hukum. Pemberian bantuan hukum dalam proses perkara pidana sebagaimana tersebut di atas adalah merupakan suatu prinsif Negara hukum bahwa pada saat pemeriksaan dan setiap waktu untuk kepentingan persiapan pembelaan perkaranya (Anwar Dan Adang, 2009).

Bentuk pemberian bantuan hukum yang dilakukan oleh LBH dalam suatu perkara pada tahapan litigasi yaitu dengan pendampingan baik di kepolisian atau di persidangan.Jika dia perkara banding bukan pendampingan tapi melakukan surat-menyurat atau pengiriman berkas 
baik sebagai pembanding atau penerima banding begitu juga kasasi (Hasil Wawancara dengan Irvan Saputra, Advokat Lembaga Bantuan Hukum Medan, Tanggal 16 Juli 2019, Pukul 15.20 Wib.)

Dalam proses litigasi, pemeriksaan suatu perkara dianggap telah selesai sebab semua tingkat upaya hukum telah digunakan secara maksimal. Akibatnya perkara tersebut akan dianggap tuntas dengan ditandai proses eksekusi. Namun bila ditelaah, sebenarnya dengan berakhirnya proses litigasi bukan berarti sengketa di antara para pihak telah benar-benar selesai, karna dengan munculnya pihak yang kalah, justru sering menumbuhkan dendam yang berkepanjangan, sehingga pihak yang kalah akan terus melakukan rongongan kepada pemenangnya agar dia tidak bisa menikmati hasil kemenangannya itu. Kondisi seperti itu justru menjadi kontraproduktif dengan tujuan penyelesaia sengketa itu sendiri, karna bukan hanya konfliknya tidak selesai secara tuntas, namun pihak yang nyata-nyata telah dinyatakan menang oleh putusan pengadilan pun pada kenyataannya tidak bisa menikmati kemenangan itu secara nyaman dan tenteram.

Non litigasi adalah proses penanganan perkara hukum yang dilakukan diluar jalur pengadilan untuk menyelesaikannya. Pemberian bantuan hukum secara non litigasi dapat dilakukan oleh advokat, paralegal, dosen, dan mahasiswa fakultas hukum lingkup pemberi bantuan hukum yang telah terakreditasi oleh menteri sesuai dengan peraturan perundangundangan.

Bentuk peran LBH, khususnya LBH Medan dalam pemberian bantuan hukum dalam tahapan non-litigasi yaitu memantau lokasi, pemerdayaan masyarakat, penyuluhan, menyurati, pendidikan hukum kritis.Dan parameter bahwa perkara telah selesai secara non litigasi (khususnya pidana) ketika kita menangani tersangka itu, ketika putusan pengadilan ada, baik di tingkat pertama, banding dan kasasi itu ketika di putuskan.Dan juga dengan surat kuasanya yang berbeda di tingkat pertama, banding maupun kasasi (Hasil Wawancara dengan Irvan Saputra, Advokat Lembaga Bantuan Hukum Medan, Tanggal 16 Juli 2019, Pukul 15.20 Wib.).

Bentuk penyelesaian perkara pidana secara non litigasi salah satunya dengan cara mediasi. Dalam proses mediasi ini terjadi permufakatan di antara para pihak yang berperkara, yang merupakan kesepakatan bersama yang di terima para pihak yang beperkara (Usman, 2012).

Dalam penyelesaian mediasi LBH sebenarnya tidak menyarankan untuk damai tetapi misalnya ada perdamaian dari kebaikan kliennya dan kliennya juga tidak mau melanjutinya itu kita serahkan pada kliennya untuk berdamai. Ada atau tidaknya pemberian suratpenghentian penyidikan perkara atau SP3tergantung perkaranya, jika perkaranya delik aduan maka selesai perkaranya dengan musyawarah dan tidak di lanjutkan lagi, akan tetapi jika perkaranya bukan delik aduan maka di berikan tanda surat penghentian penyidikan perkara atau SP3 (Hasil Wawancara dengan Irvan Saputra, Advokat Lembaga Bantuan Hukum Medan, Tanggal 16 Juli 2019, Pukul 15.20 Wib.).

Penyelesaian perkara (khususnya perkara pidana) melalui mediasi tersebut hasilnya dituangkan dalam kesepakatan tertulis yang bersifat mengikat para pihak untuk dilaksanakan dengan iktikad baik.

LBH Medan mengatakan, dalam hal kemungkinan perkara yang dulunya telah selesai secara non litigasi, dapat di kemudian hari di permasalahkan kembali, karena non litigasi ini hanya proses pencegahan atau mediasi awal. Non litigasi ini hanya pertimbangan hukum, dan jika dia delik aduan bila di cabut perkaranya selesai masalahnya (Hasil Wawancara dengan Irvan Saputra, Advokat Lembaga Bantuan Hukum Medan, Tanggal 16 Juli 2019, Pukul 15.20 Wib.).

Selain penyelesaian perkara pidana oleh LBH melalui mediasi, LBH juga melakukan penyuluhan hukum yang bertujuan untuk mewujudkan kesadaran hukum masyarakat yang lebih baik sehingga setiap anggota masyarakat menyadari dan menghayati ha dan kewajibannya sebagai warga Negara dan mewujudkan budaya hukum dalam sikap dan perilaku yang sadar, patuh dan taat terhadap hukum serta menghormati hak asasi manusia. Hak asasi manusia merupakan seperangkat hak yang melekat pada hakikat dan keberadaan manusia sebagai makhluk Tuhan Yang Maha Esa dan merupakan anugrah-Nya yang wajib di hormati, dijunjung tinggi dan di lindungi oleh negara, hukum, pemerintah, dan setiap orang demi kehormatan serta perlindungan harkat dan martabat manusia. Jadi seseorang tidak hanya dituntut untuk patuh terhadap hukum http://mahesainstitute.web.id/ojs2/index.php/jehss mahesainstitut@gmail.com

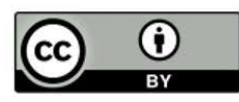


akan tetapi juga harus menghormati hak-hak orang lain yang masing-masing mempunyai harkat dan martabat yang sama serta mendapat kepastian hukum dan perlakuan yang sama di depan hukum.

\section{Hambatan yang Dihadapi Lembaga Bantuan Hukum Medan dalam Pemberian Bantuan Hukum Struktural}

Berdirinya LBH sekarang ini dapat membantu masyarakat yang miskin dan buta hukum untuk menggunakan jasa bantuan hukum secara cuma-cuma atau gratis.Menggunakan lembaga bantuan hukum bukan berarti tidak mendapatkan penasehat hukum yang cakap dan profesional.LBH jugabanyak mempunyai tenaga penasehat hukum yang cakap dan profesional sebagaimana dimiliki oleh kantor-kantor hukum yang komersil.Bahkan umumnya dari segi idealisme, penasehat hukum yang bekerja pada lembaga bantuan hukum lebih memiliki integritas yang tinggi terhadap keadilan yang di perjuangkannya (Pandu, 2001).

Dalam melaksanakan tugasnya LBH mempunyai beberapa hambatan yang menyebabkan tidak maksimalnya pemberian bantuan hukum tersebut ddiantaranya: 1) Masyarakat miskin dan buta hukum. Hampir semua masyarakat sangat rendah tingkat kesadaran hukumnya artinya mereka pada umumnya tidak tahu akan hak-hak dan kewajiban-kewajibannya dalam hukum. Mereka juga tidak tahu dan tidak mengenal bahwa didalam menghadapi dan untuk menyelesaikan masalah-masalah atau perkara-perkara ada lembaga bantuan hukum yang bantuannya dapat di perolehnya. 2) Tidak ada keberanian dari masyarakat. Seandainyapun masyarakat pencari keadilan tahu dan mengerti akan hak-haknya dan merekatahu ada bantuan hukum tersedia, akan tetapi mereka tidak mempunyai cukup keberanian untuk mempergunakan haknya itu (Nasution, 1981).

Dengan melihat permasalahan tersebut perlu adanya koordinasi antara para pihak termasuk kementerian hukum dan HAM, kepolisian kejaksaan, dan pengadilan negeri untuk meningkatkan pemahaman dan mendukung implementasi bantuan hukum.Pemerintah khususnya kementerian hukum dan HAM perlu meningkatkan sosialisasi terhadap berbagai informasi yang berkaitan dengan ketersediaan bantuan hukum bagi para pihak yang membutuhkannya.

Dengan demikian masyarakat paham bahwa bantuan hukum ditunjukan bukan hanya untuk orang yang mampu dalam segi finansial namun juga terhadap orang miskin sebagai penerima bantuan hukum.Adanya UU bantuan hukum ini diharapkan menjadi akses keadilan dan kesamaan hak dihadapan hukum yang dapat dirasakan oleh semua kelompok masyarakat.

Tabel 1 Jumlah Perkara Yang Masuk Di LBH Medan Tahun 2018

\begin{tabular}{lllll}
\hline \multirow{2}{*}{ No } & \multirow{2}{*}{ Keterangan } & \multirow{2}{*}{ Jumlah } & Jenis & \\
\cline { 4 - 5 } & & & Pidana & Perdata \\
\hline 1 & Pengaduan & 152 & 82 & 70 \\
\hline 2 & Selesai di proses & 33 & 16 & 17 \\
\hline 3 & Konsultasi & 119 & 66 & 53 \\
\hline
\end{tabular}

Sumber data : Bagian Pelayanan Informasi LBH Medan

Jumlah perkara yang masuk di LBH Medan tahun 2018 sebanyak 152 perkara dengan jenis perkara pidana sebanyak 82 dan perdata sebanyak 70 perkara. Dari pengaduan perkara tersebut LBH Medan melakukan konsultasi kepada penerima bantuan hukum sebanyak 119 dengan jenis perkara pidana 66 dan perdata 53 perkara, sedangkan perkara yang sudah selesai di proses sebanyak 33 perkara dengan jenis perkara pidana sebanyak 16 dan perdata sebanyak 17 perkara. Tabel 2Jumlah Perkara Yang Masuk Di LBH Medan Tahun 2019

\begin{tabular}{lllll}
\hline \multirow{2}{*}{ No } & \multirow{2}{*}{ Keterangan } & Jumlah & Jenis & \\
\cline { 4 - 5 } & & 232 & Pidana & Perdata \\
\hline $\mathbf{1}$ & Pengaduan & 28 & 125 & 107 \\
\hline 3 & Selesai di proses & 204 & 13 & 15 \\
\hline
\end{tabular}

Sumber data : Bagian Pelayanan Informasi LBH Medan 
Jumlah perkara yang masuk di LBH Medan tahun 2019 sebanyak 232 perkara dengan jenis perkara pidana sebanyak 125 dan perdata sebanyak 107 perkara. Dari pengaduan perkara tersebut LBH Medan melakukan konsultasi kepada penerima bantuan hukum sebanyak 204 dengan jenis perkara pidana 112 dan perdata 92 perkara, sedangkan perkara yang sudah selesai di proses sebanyak 28 perkara dengan jenis perkara pidana sebanyak 13 dan perdata sebanyak 15 perkara.

Ketidak aktifan pemberi dan penerima bantuan hukum, disebabkan karena kondisi yang tidak stabil atau lagi sakit, sehingga membuat proses penyelesaian perkara hingga berlarut-larut. Biaya operasional, dari pemerintah begitu kecil karna dalam memberikan bantuan hukum secara cuma-cuma kepada masyarakat marjinal, buta hukum, dan masyarakat miskin mengeluarkan biaya yang begitu besar sehingga ketidak adanya biaya tersebut dapat menghambat pelaksanaan bantuan hukum. Ketidak adanya bukti yang cukup, karna dalam menyelesaikan suatu perkara khususnya perkara pidana harus di sertai dengan bukti-bukti yang memadai agar dapat menguatkan dan membuktikan fakta yang sebenarnya. Tidak ada saksinya, dikarenakan mereka yang melihat menyembunyikan diri dan tidak mau bersaksi karna mereka takut berhadapan dengan hukum, sehingga dapat menghambat pembuktian dalam menyatakan kebenaran, karna tidak ada perkara pidana yang luput dari keterangan saksi. Tidak jelas perkara yang di sampaikan, disebabkan sebagian mereka buta huruf dan menjelaskan kronologis secara berbelit-belit sehingga tidak pasti dasar hukumnya. Intervensi dari pihak lain (tekanan politik, tekanan aparatur), dengan cara menakut-nakuti dapat membuat pemberi dan penerima bantuan hukum menjadi takut dan tidak melanjutkan perkaranya di pengadilan (Hasil Wawancara dengan Irvan Saputra, Advokat Lembaga Bantuan Hukum Medan, Tanggal 16 Juli 2019, Pukul 15.20 Wib.).

Adapun tanggapan penerima bantuan hukum An.Mhd Rusli, dalam menerima bantuan hukum struktural yang diberikan oleh pemberi bantuan hukum yaitu penerima bantuan hukum merasa cukup puas dalam pelayanan, pendampingan, informasi, dan biaya gratis.

Masalah bantuan hukum bagi rakyat miskin dimana saja bukan semata-mata masalah hukum, melainkan sangat kompleks. Masalah hukum menyangkut juga aspek-aspek ekonomi, sosial, politik, bahkan juga kultur. Cara mengatasi hambatan-hambatan itu, tidak cukup dengan hanya memajukan hukumnya, dan lebih tidak cukup lagi jika hanya dilakukan pembaharuan ekonomi, melainkan di perlukan secara simultan dibangun pula struktur sosial, politik bahkan perubahan kultur. Kesemua ini tentu saja tidak lepas dari pada pemerintah yang berkuasa (political will) (Hasil Wawancara dengan Irvan Saputra, Advokat Lembaga Bantuan Hukum Medan, Tanggal 16 Juli 2019, Pukul 15.20 Wib.)

Dengan melihat permasalahan tersebut ada beberapa cara yang dilakukan oleh LBH Medan agar tetap efektif dan tidak mempengaruhi pemberian bantuan hukum yaitu dengan cara: 1) komunikasi antar tim dengan saling mengingatkan; 2) mencari donatur (kerjasama dengan pemerintah); 3) diskusi; 4) survei lapangan; 5) konsultasi hUkum; 6) mencari ilmu-ilmu baru atau mencari aturan-aturan yang menguntungkan kliennya (Hasil Wawancara dengan Irvan Saputra, Advokat Lembaga Bantuan Hukum Medan, Tanggal 16 Juli 2019, Pukul 15.20 Wib.).

LBH berperan besar dalam access to justice bagi masyarakat yang tidak mampu karena berperan besar dalam memberikan solusi dari tingkat konsultasi, tingkat pendampingan bagi masyarakat di luar pengadilan (non-litigasi) hingga tingkat pendampingan bagi masyarakat di tingkat pengadilan (litigasi).

Dengan demikian bantuan hukum ditunjukan bukan hanya untuk orang yang mampu dalam segi finansial namun juga terhadap orang miskin sebagai penerima bantuan hukum.Adanya UU Bantuan Hukum ini diharapkan menjadi akses keadilan dan kesamaan hakdihadapan hukum yang dapat dirasakan oleh semua kelompok masyarakat.

\section{SIMPULAN}

Aturan hukum terhadap pemberian bantuan hukum struktural dalam proses penyelesaian perkara pidana secara litigasi dan non litigasi adalah: Undang-undang Nomor 16 Tahun 2011 Tentang Bantuan Hukum, yang dilengkapi dengan peraturan pelaksananya antara lain: Peraturan 7. http://mahesainstitute.web.id/ojs2/index.php/jehss (v) mahesainstitut@gmail.com

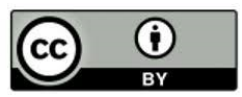


Pemerintah Nomor 42 Tahun 2013 Tentang Syarat dan Tata Cara Pemberian Bantuan Hukum Dan Penyaluran Dana Bantuan Hukum. Peraturan Menteri Hukum dan Hak Asasi Manusia Nomor 3 Tahun 2013 Tentang Tata Cara Verifikasi dan Akreditasi Lembaga Bantuan Hukum atau Organisasi Kemasyarakatan. Peraturan Menteri Hukum Dan Hak Asasi Manusia Nomor 10 Tahun 2015 Tentang Peraturan Pelaksanaan Peraturan Pemerintah Nomor 42 Tahun 2013 Tentang Syarat Dan Tata Cara Pemberian Bantuan Hukum Dan Penyaluran Dana Bantuan Hukum. Peraturan Menteri Hukum Dan Hak Asasi Manusia Nomor 01 Tahun 2018 Tentang Paralegal Dalam Pemberian Bantuan Hukum. Undang-undang Nomor 18 Tahun 2003 Tentang Advokat. Bantuan internal dalam memberikan bantuan hukum yaitukhususnya LBH Medandipakai Standar Operasional Prosedur (SOP), dan peraturan-peraturan lain yang menunjang salah satunya seperti KUHAP.

Bantuan Litigasi yaitu melakukan pendampingan baik di kepolisian, dikejaksaan dan dipersidangan dengan cuma-cuma. Jika perkaranya perkara banding dan kasasi maka dilakukan surat-menyurat atau pengiriman berkas baik sebagai pembanding atau penerima banding, pemohon kasasi maupun termohon kasasi. Non litigasi adalah proses penanganan hukum yang dilakukan diluar jalur pengadilan untuk menyelesaikannya, meliputi penyuluhan hukum, konsultasi hukum, investigaasi perkara baik secara elektronik maupun nonelektronok, penelitian hukum, mediasi, negoisasi, pemberdayaan masyarakat, pendampingan diluar pengadilan, drafting dokumen hukum.

Hambatan yang di hadapi LBH Medan dalam memberikan bantuan hukum struktural yaitu: 1) ketidak aktifan pemberi dan penerima bantuan hokum;2) Biaya operasional; 3) Tidak adanya bukti yang cukup; 4) Tidak ada saksinya; 5) Tidak jelas perkara yang disampaikan; 6) Intervensi dari pihak lain (tekanan politik, tekanan aparatur). Dengan melihat permasalahan tersebut ada beberapa cara yang di lakukan oleh LBH Medan agar tetap efektif dan tidak mempengaruhi pemberian bantuan hukum yaitu: 1) Komunikasi antar tim dengan saling mengingatkan; 2) Mencari donator (kerjasama dengan pemerintah); 3) Diskusi; 4) Survei lapangan; 5) Konsultasi hokum; 6) Mencari ilmu-ilmu baru atau mencari aturan-aturan yang menguntungkan kliennya.

\section{DAFTAR PUSTAKA}

Abdurrahman, (1983), Aspek-Aspek Bantuan Hukum Di Indonesia, Jakarta: PT. Cendana Press

Anwar, Y., Dan Adang, (2009), Sistem Peradilan Pidana, Bandung: PT. Widya Padjadjaran

Buyung, A., (1981), Bantuan Hukum Di Indonesia, Jakarta: PT. Djaya Pirusa.

Buyung, A., (1988), Bantuan Hukum Di Indonesia, Jakarta: PT. LP3ES.

Harahap, M.Y., (1999), Pembahasan Permasalahan Dan Penerapan KUHAP, Penyidik Dan Penuntutan, Jakarta: PT. Sinar Grafika

Kusnadi, M., dan Saragih, B.R., (1983), Susunan Pembagian Kekuasaan Menurut Sistem Undang-Undang Dasar 1945, Jakarta: PT. Grapindo.

Pandu, Y, (2001), Klien Dan Penasehat Hukum Dalam Perspektif Masa Kini, Jakarta: PT. Indonesia Legal Center Publising

Rahardjo, S., (2003), Sisi-sisi Lain Dari Hukum Di Indonesia, Jakarta: PT. Buku Kompas,

Rosalina, M., (2018), Aspek Hukum Paralegal Sebagai Pemberi Bantuan Hukum Terhadap Masyarakat Miskin Dan Marginal Dalam Mencari Keadilan, Jurnal Hukum Kaidah, 17(2): 63-76.

Sihombing, E.N.A.M. (2019). Eksistensi Paralegal dalam Pemberian Bantuan Hukum Bagi Masyarakat Miskin, Jurnal Ilmiah Penegakan Hukum. 6 (1) 2019: 70 - 77.

Sudirman, A., (2007), Hati Nurani Hakim Dan Putusannya, Jakarta: PT. Citra Aditia Bakti

Sugono, B., dan Harianto, A., (2017), Bantuan Hukum dan Hak Asasi Manusia, Bandung: PT. Mandar Maju

Usman, R., (2012), Mediasi Di Pengadilan Dalam Teori Dan Praktek, Jakarta: PT. Sinar grafika

Undang-Undang Dasar Republik Indonesia Tahun 1945

Undang-Undang RI Nomor 18 Tahun 2003 tentang Advokat

Undang-Undang RI Nomor 16 Tahun 2011 tentang Bantuan Hukum

Peraturan Pemerintah Nomor 42 Tahun 2013 tentang Syarat Dan Tata Cara Pemberian Bantuan Hukum Dan Penyaluran Dana Bantuan Hukum

Peraturan Menteri Hukum Dan Hak Asasi Manusia Nomor 01 Tahun 2018 tentang Paralegal Dalam Pemberian Bantuan Hukum

Pengertian Efektivitas dan Efisiensi, www.antarberita.blogspot.com, diakses pada tanggal 1 September 2013 Pukul 07.22 Wib.

Www http://mahesainstitute.web.id/ojs2/index.php/jehss

M. mahesainstitut@gmail.com 
Fajargus Laia, Susilawati \& Maria Rosalina, Efektifitas Pemberian Bantuan Hukum

Perbedaan Litigasi dan Non-litigasi, www.komisiinformasi. bantenprov.com, diakses pada tanggal 20 Juli 2016 Pukul 11:49 Wib. 